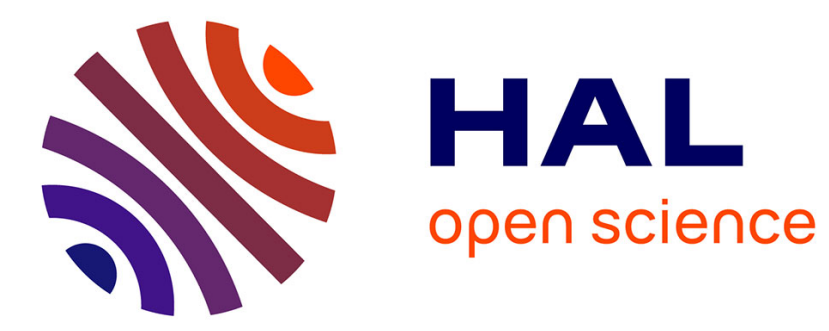

\title{
Introduction. Access Benefit-Sharing and the Nagoya Protocol: The Confluence of Abiding Legal Doctrines
} Arianna Broggiato, Tom Dedeurwaerdere, Fulya Batur, Brendan Coolsaet

\section{To cite this version:}

Arianna Broggiato, Tom Dedeurwaerdere, Fulya Batur, Brendan Coolsaet. Introduction. Access Benefit-Sharing and the Nagoya Protocol: The Confluence of Abiding Legal Doctrines. Implementing the Nagoya Protocol: comparing Access and Benefit-Sharing regimes in Europe, 2015, 10.1163/9789004293212_002. hal-01743918

\section{HAL Id: hal-01743918 \\ https://hal.science/hal-01743918}

Submitted on 26 Mar 2018

HAL is a multi-disciplinary open access archive for the deposit and dissemination of scientific research documents, whether they are published or not. The documents may come from teaching and research institutions in France or abroad, or from public or private research centers.
L'archive ouverte pluridisciplinaire HAL, est destinée au dépôt et à la diffusion de documents scientifiques de niveau recherche, publiés ou non, émanant des établissements d'enseignement et de recherche français ou étrangers, des laboratoires publics ou privés. 
archives-ouvertes

\section{Access Benefit-Sharing and the Nagoya Protocol: The Confluence of Abiding Legal Doctrines}

Arianna Broggiato, Tom Dedeurwaerdere, Fulya Batur, Brendan Coolsaet

\section{To cite this version:}

Arianna Broggiato, Tom Dedeurwaerdere, Fulya Batur, Brendan Coolsaet. Access Benefit-Sharing and the Nagoya Protocol: The Confluence of Abiding Legal Doctrines. Implementing the Nagoya Protocol : comparing Access and Benefit-Sharing regimes in Europe, 2015, <10.1163/9789004293212_002>. $<$ hal-01743918>

\section{HAL Id: hal-01743918 https: / hal.archives-ouvertes.fr/hal-01743918}

Submitted on 26 Mar 2018

HAL is a multi-disciplinary open access archive for the deposit and dissemination of scientific research documents, whether they are published or not. The documents may come from teaching and research institutions in France or abroad, or from public or private research centers.
L'archive ouverte pluridisciplinaire HAL, est destinée au dépôt et à la diffusion de documents scientifiques de niveau recherche, publiés ou non, émanant des établissements d'enseignement et de recherche français ou étrangers, des laboratoires publics ou privés. 


\title{
Introduction. Access Benefit-Sharing and the Nagoya Protocol: The Confluence of Abiding Legal Doctrines
}

\author{
Arianna Broggiato, Tom Dedeurwaerdere, Fulya Batur and \\ Brendan Coolsaet
}

The Nagoya Protocol on Access to Genetic Resources and the Fair and Equitable Sharing of Benefits Arising from their Utilization (hereafter, "the Nagoya Protocol") to the Convention on Biological Diversity (CBD) was adopted in 2010. Its objective is the fair and equitable sharing of the benefits arising from the utilization of genetic resources and traditional knowledge, with the aim of contributing to the conservation of biological diversity and the sustainable use of its components. As an international agreement, the Nagoya Protocol complements the international legal regime related to the management of genetic resources and traditional knowledge. However, this introductory chapter illustrates an innovative perspective ${ }^{1}$ aimed at demonstrating that the inception of this legal regime long predates the discussion on access and benefit-sharing (ABS) of the CBD and is the product of the interaction of different legal fields: the international laws on development, trade, environment and intellectual property protection. The negotiation history (see Section II of this chapter) of the different international documents related to these domains shows three core motives that have driven international policy makers and civil society in promoting the development of a specific regime for access and benefit-sharing as a protocol to the CBD. The first motive is the fight against misappropriation of natural resources, which is predominant in the global social movements focusing on the right to development and environmental justice. The specific misappropriation of genetic resources and traditional knowledge (TK) was particularly brought to light through the debate on the emergence of highly exclusive intellectual property rights' legislations in various countries around the world. The second political motive is the ethical duty to conserve the Earth's limited resources, which gained public attention through the emergence of the internationally prominent environmental movement in the 1970ies, and was

1 The hypothesis that the concept of benefit-sharing long predated the discussion on ABS of the CBD and it is the product of the interaction between three fields of international law is here presented for the first time by the authors of this chapter, therefore the argumentations lack in references to previous literature. 
institutionalized through the 1972 Declaration of the United Nations Conference on the Human Environment ${ }^{2}$ (hereafter, "Stockholm Declaration") and the numerous subsequent international and regional conservation treaties. ${ }^{3}$ The third motive is the promotion of international cooperation for scientific research in support of the two first motives.

Traces of these three political motives can be found in all of the main international documents related to genetic resources and traditional knowledge. They have however had different weights in the development of the different sectors of international law making. The core foundation of the first motive is the fundamental principle of sovereignty of a State over its natural (tangible) resources, which inspired the first claim to the right to development and which already included the basic principles of benefit-sharing within the early international documents. ${ }^{4}$ This motive is still very important in the current debate, in particular because of its focus on people centred development which announced the current emphasis on the protection of traditional knowledge associated with genetic resources. The environmental motive emerged to balance the risk of the depletion of the resource. However, although biodiversity conservation is the official underlying principle of the CBD, it can be argued that the more utilitarian "sustainable use" objective focusing on a monetization of biodiversity got the upper hand. ${ }^{5}$ Finally, the central role of research and the consequent necessity to support the development of scientific capabilities of developing countries was felt strongly in the 1970s. It nonetheless lost its weight at a later stage and disappeared from the international law making, to arguably regain momentum in the beginning of this century through

2 Declaration of the United Nations Conference on the Human Environment, U.N. Doc. A/Conf.48/14/Rev. 1 (1973); 11 ILM 1416 (1972).

3 Among many others: the 1972 Convention concerning the Protection of the World Cultural and Natural Heritage (UNESCO); the 1973 Agreement on the Conservation of Polar Bears; the 1973 Convention on International Trade in Endangered Species of Wild Fauna and Flora (CITES); the 1979 Convention on the Conservation of Migratory Species of Wild Animals (CMS).

4 UNGA Resolution 1803 (XVII) of 14 December 1962 "Permanent sovereignty over natural resources"; UNGA Resolution 523 of 12 January $195^{2}$ on "Integrated economic development and commercial agreements."

5 In 1992, germplasm and associated traditional knowledge are increasingly considered as raw material for the biotechnology industry and, thus, as a tradable economic goods. See Alain Lipietz, "Enclosing the Global Commons: Global Environmental Negotiations in a Northsouth Conflictual Approach," in The North the South and the Environment, eds. Bhaskar, V. and Glyn, A. (London: Earthscan, 1995): 118-142; Marc Hufty, "La gouvernance internationale de la biodiversité," Etudes internationales 32 (2001): 5-29; Catherine Aubertin and Geoffroy Filoche, "The Nagoya Protocol on the use of genetic resources: one embodiment of an endless discussion," Sustentabilidade em Debate 2 (2011). 
the legal regimes governing agricultural plant genetic resources and within the Nagoya Protocol.

The chapter's hypothesis is that the adoption of the Nagoya Protocol to the Convention on Biological Diversity in 2010 is an attempt to strike a balance between these three political motives, and their underlying legal and political doctrines. The Protocol is expected to lay the ground for the long needed legal certainty for the many players involved in sustainable use, conservation and international exchange of genetic resources and traditional knowledge. The way that the three motives however will be translated into practices will depend on the concrete implementation in the national countries' legislations across the world. For this reason, it is important to build international experience with balanced implementation efforts that satisfy these three motives and to learn from best country practices. The authors of this collective volume aim to contribute to efforts in that direction, by gathering the most up to date knowledge on the on-going implementation efforts of the Nagoya Protocol in Europe.

This introductory chapter will therefore first describe the ABS legal framework by introducing the main ABS legal instruments and their characteristics (see Section I). It will then illustrate the reach and effects of the three aforementioned policy motives that can be identified in the international law of genetic resources and traditional knowledge management (Section II). To conclude the third Section of the chapter will describe the structure and the research questions behind this publication.

\section{The ABS Legal Framework}

\section{The Convention on Biological Diversity and the Nagoya Protocol}

The Nagoya Protocol, adopted in 2010 and entered into force on October 12 2014, was negotiated under the Convention on Biological Diversity. The Convention on Biological Diversity, signed in May 1992 and entered into force in December 1993, is the first international conservation agreement addressing biological diversity as a whole rather than through sectorial approaches focusing on specific species, ecosystems or sites. Its objectives are the conservation of biological diversity, the sustainable use of its components and the fair and equitable sharing of the benefits arising from the utilization of genetic resources. ${ }^{6}$ The broad objectives of the CBD are a consequence of the opposing interests of developing and developed countries: ${ }^{7}$ the former ones were not

6 CBD Article 1.

7 Thomas Greiber, et al., An Explanatory Guide to the Nagoya Protocol on Access and Benefitsharing (Gland: IUCN, 2012), 4. 
willing to accept a commitment only focused on biodiversity conservation, so the "Rio package deal" conditioned their support for conservation obligation to socio-economic considerations and to the obligation of developed countries (more advanced in biotechnology) to share the benefits gained from the use of genetic material. The Convention is a framework treaty setting down the basic principles Parties have to follow in providing for the conservation and sustainable use of biological diversity and in granting access to their genetic resources, leaving to each Party to implement those principles in its own territory and according to its own policies and legislations.

The conservation and sustainable use clauses of the Convention impose to Contracting Parties obligations to develop national strategies, plans or programmes; to identify components of biological diversity, monitor them and to identify processes and activities which might have an adverse impact on the biological diversity; and to adopt measures for in situ conservation and ex situ conservation (see Section II.2). Research which contributes to the conservation and sustainable use of biological diversity shall be promoted by Contracting Parties, particularly in developing countries.

The Convention recognizes the states' sovereign right to exploit their own biological resources and that the authority to determine access to genetic resources rests within the national government and is subject to national legislation. Access to genetic resources shall be subject to prior informed consent (PIC) of the country providing the resources, if this is required by its legislation, and should be granted on mutually agreed terms (MAT) between the provider and the user. Therefore the ABS concept is based on the bilateral relationship between a provider of a genetic resource and a user of this resource.

The Convention applies in relation to each Contracting Party to components of biological diversity in areas within the limits of its national jurisdiction and to processes and activities carried out under its jurisdiction or control. While the provisions on access apply only to genetic resources, the provisions on conservation and sustainable use cover all biological diversity, including genetic resources. The Convention covers access to genetic resources in countries of origin after the entering into force of the CBD in those countries. It is important to remember that most of the genetic resources collected in ex situ collections (see Section I.3) were collected prior to the CBD entering into force for the country holding the collection.

As far as the relationship with other international treaties on biological diversity is concerned, the CBD provides that its provisions shall not affect the rights and obligations of any Contracting Party deriving from any existing agreement, except where the exercise of those rights and obligations would 
cause serious damage or threat to biological diversity. ${ }^{8}$ The CBD Conference of the Parties recognized later on the importance of the International Treaty on Plant Genetic Resources for Food and Agriculture (ITPGRFA) ${ }^{9}$ (See Section I.2).

Article 15.7 of the CBD prescribes that each Contracting Party shall take legislative, administrative or policy measures with the aim of sharing in a fair and equitable way the results of research and development and the benefits arising from the commercial and other utilization of genetic resources with the Contracting Party providing them.

Few CBD Parties had the legal capacity to translate the CBD provisions into national $\mathrm{ABS}$ legislations and most industrialized Parties were reluctant to adopt measures supporting effective benefit-sharing. As a consequence several megadiverse countries adopted restrictive legislation on access to genetic resources, in order to protect their resources from the risk of "biopiracy." This lead to a visible lack of implementation of the CBD's third objective of sharing of the benefits arising from the utilization of genetic resources. ${ }^{10}$ The first attempt to provide more detailed guidance on ABS was the adoption by the CBD Conference of the Parties of the non-legally binding Bonn Guidelines ${ }^{11}$ in 2002. The Bonn Guidelines aimed at guiding governments in the establishment of legislative, administrative or policy measures on ABS, but still a few countries adopted domestic ABS legislations after their adoption.

In the same year, to further advance the third objective of the CBD, the 2002 World Summit on Sustainable Development in Johannesburg called for the negotiation of an international regime to promote and safeguard the fair

$8 \quad$ CBD Article 22.

9 CBD Decision VI/6. For a complete analysis of the relationships between the CBD and the ITPGRFA see Study on the relationship between an international regime on ABS and other international instruments and fora which govern the use of genetic resources The International Treaty on Plant Genetic Resources for Food and Agriculture and the Food and Agriculture Organisation's Commission on Genetic Resources for Food and Agriculture. Prepared by Jane Bulmer, IUCN Environmental Law Centre. UNEP/CBD/WG-ABS/7/ $\mathrm{INF} / 3 /$ Part.1. 3 March 2009.

Elisa Morgera et al., The 201 o Nagoya Protocolon Access and Benefit-sharing in Perspective. Implications for International Law and Implementation Challenges (Leiden: Martinus Nijhoff, 2013), 5 .

11 Bonn Guidelines on Access to Genetic Resources and Fair and Equitable Sharing of the Benefits Arising out of their Utilization (Bonn Guidelines), CBD Decision 6/24, "Access and Benefit-sharing as Related to Genetic Resources" (27 May 2002) UN Doc UNEP/CBD/ $\mathrm{COP} / 6 / 20$. 
and equitable sharing of the benefits arising from the utilization of genetic resources..$^{12}$ In 2004 the CBD Conference of the Parties mandated its Ad Hoc Open-ended Working Group on Access and Benefit-sharing to elaborate and negotiate an international regime on access to genetic resources and benefitsharing in order to effectively implement Article 15 and Article 8(j) of the Convention and its three objectives. The outcomes of these negotiations brought to the adoption of the Nagoya Protocol in October 2010. Its objective is the fair and equitable sharing of the benefits arising from the utilization of genetic resources and traditional knowledge, with the aim of contributing to the conservation of biological diversity and the sustainable use of its components.

The Protocol is aimed at operationalizing the third objective of the CBD by setting up rules and procedures on access, benefit-sharing, and compliance. Therefore it is further detailing the rights and obligations of the CBD in relation to genetic resources and traditional knowledge associated with such resources, thus developing further the concept of benefit-sharing. The Protocol clarifies key concepts of the ABS field, such as "utilization of genetic resources" and "derivatives"; it illustrates the key elements of national measures in provider and user countries; and it strengthens the link between ABS and traditional knowledge. It applies to access over genetic resources as well as traditional knowledge associated with them, and to the benefits arising from the "utilization" of such resources and knowledge, that is to say genetic resources over which States exercise sovereign rights. The reference to the utilization in the description of the scope expands the material scope of application to naturally occurring biochemical compounds, even if they do not contain functional units of heredity. ${ }^{13}$ The Protocol includes innovative clauses on the possible future negotiation of a global multilateral benefit-sharing mechanism, that could be used for sharing the benefits arising out of the utilization of genetic resources coming from areas outside national jurisdiction; and the cooperation efforts for transboundary situations of genetic resources found in situ within the territory of more than one Party, or TK associated with genetic resources shared by one or more indigenous and local communities in several Parties. It also strengthens the CBD obligation to "promote and encourage research which contributes to the conservation and sustainable use of biological diversity, particularly in developing countries," indicating the adoption of "simplified measures on access for non-commercial research purposes, taking into account the need to address a change of intent for such research." Doc A/CONF.199/20, Resolution 2: Johannesburg Plan of Implementation, paragraph 44.o. 
The Protocol's system of compliance is based on a mixture of international and domestic measures, such as the obligation on users to respect national laws on access; the monitoring measures including the obligations to designate checkpoints, to issue internationally recognized certificate of compliance as proof of legal acquisition in provider countries; the establishment of an Access and Benefit-sharing Clearing House for sharing information related to access and benefit-sharing; and the future discussions on procedures and institutional mechanisms to promote compliance and to address cases of noncompliance in a cooperative way.

The Protocol is the result of six years of intergovernmental negotiations and of the consensus adoption by 193 CBD Parties at the tenth meeting of the Conference of the Parties (COP) to the CBD of the compromise text proposed by the Japanese delegation, in order to break through the deadlock of the negotiations. This politically very successful strategy prevented the rigorous legal consistency check that normally take place at the end of a treaty negotiation, therefore this created some room for interpretative questions. ${ }^{14}$

As far as relationship with other international treaties on genetic resources is concerned, the Protocol recognizes the specialized international ABS instruments that are consistent with and does not run counter to the objectives of the CBD and the Protocol and does not apply for the Parties to such specialized instruments in respect of the specific genetic resources covered by and for the purpose of the specialized instruments. ${ }^{15}$ However the Protocol call for a mutually supportive manner of implementation with other international instruments relevant to the Protocol. ${ }^{16}$

International Instruments for Plant Genetic Resources for Food and Agriculture

The need to design an ad hoc instrument for the conservation, but also the sustainable and equitable use of plant genetic resources for food and agriculture (PGRFA) while ensuring the widest possible access to germplasm for research and development was espoused by the international community as early as the 1980's. Policy discussions on the international management and status of plant genetic resources started in the 1970's: they led to the adoption of the FAO Global System for the Conservation and Utilisation of PGRFA in 1983. This package addressed both in situ and ex situ agrobiodiversity management, and comprised of a non-binding yet promising international agreement,

14 Elisa Morgera et al., The 2010 Nagoya Protocol on Access and Benefit-sharing.

15 Nagoya Protocol Article 4.4.

16 Nagoya Protocol Article 4.3. 
the International Undertaking for Plant Genetic Resources ${ }^{17}(\mathrm{IU})$. The International Network of ex situ Collections was established along with the Commission on Plant Genetic Resources for Food and Agriculture, the first permanent intergovernmental body specifically dedicated to PGRFA. The Undertaking, adopted at the twenty-second session of the FAO Conference held in Rome professed its goals to include the exploration, preservation, evaluation and availability of PGRFA for plant breeding and scientific purposes. The IU identified plant genetic resources as a heritage of mankind (HM). The Undertaking originated from the early practice within the Consultative Group on International Agricultural Research (CGIAR $)^{18}$ of granting free access and free exchange of plant genetic resources for food and agriculture, then however this practice was hampered by a shortage of funds for public research and so by the privatization of agricultural research in the 8os. The system was born and drafted as an open access system, and then it was characterized by contrasting interests: on one hand the developing countries wanted to keep control over the abundant PGRFA, while the developed ones wanted to maintain control over the refined products of breeding for engineering. So the battle was between sovereignty on one side and intellectual property on the other hand, as the two different tools chosen respectively by developing and developed states to protect their interests.

In the meantime, the CBD and its national sovereignty principle got adopted in 1992, followed by the international minimum intellectual property (IP) protection standards of the Agreement on Trade-Related Aspects of Intellectual Property Rights ${ }^{19}$ (TRIPS Agreement) two years later, urging for an adaptation of the international agricultural community to the new legal landscape. The Commission on Genetic Resources for Food and Agriculture set out to re-negotiate the legal component of the FAO Global System, an effort that took "six and a half arduous years," mostly because of the polarisation between developed and developing countries. The debates initiated before the UN Food and Agriculture Organisation came about as "heavily politicised, with concerns about intellectual property rights and national germplasm embargoes" that were set up through other international instruments. Adopted by the

17 Resolution $8 / 83$ of the Twenty-second Session of the FAO Conference, Rome, $5^{-23}$ November 1983 .

18 The CGIAR s an international organisation which funds and co-ordinates research into agricultural crop breeding with the goal of "reducing rural poverty, increasing food security, improving human health and nutrition, and ensuring more sustainable management of natural resources." It was established on May 19, 1971.

19 Agreement on Trade-Related Aspects of Intellectual Property Rights, 1869 UNTS 299; 33 ILM 1197 (1994). 
Conference in November 2001, the International Treaty on Plant Genetic Resources for Food and Agriculture came into force in June 2004. The objectives of the Treaty are "the conservation and sustainable use of plant genetic resources for food and agriculture and the fair and equitable sharing of the benefits arising out of their use, in harmony with the Convention on Biological Diversity, for sustainable agriculture and food security." In its conservation angle, it advocates an "integrated approach to the exploration, conservation and sustainable use" of agrobiodiversity, where both in situ and ex situ efforts are equally acknowledged. The FAO Treaty re-affirms the sovereignty of States over their own plant genetic resources for food and agriculture. Through the exercise of this sovereignty Member States determine their own access policy. Moreover, they agreed to establish a Multilateral System (MLS) ${ }^{20}$ to facilitate access to plant genetic resources for food and agriculture, and to share, in a fair and equitable way, the benefits arising from the utilization of these resources. This facilitated access shall be pursuant to the standard material transfer agreement (SMTA). ${ }^{21}$ Any benefits that arise from the use of these resources under the MLS shall be shared fairly and equitably. ${ }^{22}$ Thus facilitated access is required for a closely defined set of circumstances: for the purpose of utilization and conservation for research, breeding and training for food and agriculture. ${ }^{23}$ The scope of the ITPGR covers all plant genetic resources for food and agriculture, ${ }^{24}$ however, the MLS was established to deal with a subset of those resources, which are listed in Annex I to the ITPGR. Let alone a comprehensive evaluation of the Multilateral System that goes beyond the scope of this chapter, there are many issues of efficiency that underpin the System and do not create enough incentives for the private sector to step into it.

As far as the relationship with other international instruments dealing with genetic resources the ITPGR is a subsequent agreement to the CBD and arguably a form of lex specialis, ${ }^{25}$ therefore its MLS prevails on the

The MLS facilitates access to 35 crop species and 29 forage species upon which the world is interdependent and which are critical to food security. These are held by governments and the International Agricultural Research Centres of the Consultative Group on International Agricultural Research.

$21 \quad$ See ITPGR Resolution 2/2006.

22 ITPGR Article 13.2.

23 ITPGR Article 12.

24 ITPGR Article 3.

25 Study on the relationship between an international regime on ABS and other international instruments and fora which govern the use of genetic resources The International Treaty on Plant Genetic Resources for Food and Agriculture and the Food and Agriculture Organisation's Commission on Genetic Resources for Food and Agriculture. Prepared by 
CBD obligations. ${ }^{26}$ The ITPGR should be implemented in harmony, and in mutual supportiveness, with the CBD and the Nagoya Protocol.

\section{$3 \quad$ Conservation in ex situ Collections}

Ex situ conservation is defined by Article 2 of the CBD as "the conservation of components of biological diversity outside of their natural habitats." Ex situ collections are collections of genetic resources held for example in gene banks, botanical gardens, arboreta, zoos, in vitro storage and DNA storage. According to the CBD, contracting Parties shall use ex situ conservation methods, preferably in the country of origin of such components, to support in situ measures. Moreover, contracting Parties are required to adopt ex situ measures to facilitate the rehabilitation of threatened species and the reintroduction of them into their natural habitats. This confines their significance to that of returning species to their habitual situ. However, culture collections conserving microbial genetic diversity have acquired a growing importance within the ABS panorama, thanks to the inclusion of microbial genetic resources within the scope of the CBD and the growing scientific importance of microbial genetic resources in the last decades.

Most research undertaken at the level of ex situ collections, if not all, is of a non-commercial nature, aimed at improving understanding of genetic diversity and how to best conserve it. ${ }^{27}$ Moreover, most of the genetic resources found ex situ were accessed before the entry into force of the CBD in biodiversity-rich countries. The Bonn Guidelines prescribes that for $e x$ situ collections, prior informed consent should be obtained from the competent national authority(ies) and/or the body governing the ex situ collection concerned as appropriate. It is important to notice that some ex situ collections, such as botanical garden and herbaria consider the whole of their collection as falling under the obligations of the CBD, regardless of the date of the first collection of the resources, due to ethical and pragmatic reasons.

Most of ex situ collections networks have adopted non-binding ABS codes of conduct, best practices and /or guidelines, such as for example:

Jane Bulmer, IUCN Environmental Law Centre. UNEP/CBD/WG-ABS/7/INF/3/Part.1. 3 March 2009, 9.

26 Where Parties to the CBD are Contracting Parties to the ITPGR, in accordance with Article 30 of the Vienna Convention on the Law of Treaties, on the application of successive treaties relating to the same matter, then the legal relationship of the ITPGR would prevail among them to the extent of the scope of the ITPGR.

27 Thomas Greiber, et al., An Explanatory Guide, 15. 
- The Micro-Organisms Sustainable Use and Access Regulation International Code of Conduct (MOSAICC) developed within the framework of culture collections in 1999 and revised in 2009. It is currently under revision in light of the Nagoya Protocol and translated into the Transparent User Friendly System of Transfer for Science and Technology (TRUST);

- The International Plant Exchange Network (IPEN) Code of Conduct for botanic garden governing the acquisition, maintenance and supply of living plant material, developed in 2001;

- The Consortium of European Taxonomic Facilities (CETAF) Code of Conduct and Best Practice for Access and Benefit-sharing, developed in 2012.

The goal of an ABS codes of conduct is triple: first a political recognition and support of the international ABS framework by the institution drafting the code; second the raising awareness among the practitioners working within a group of researchers; and third the facilitation of exchanges of resources by the creation of a group where exchanges are governed by the same standardized rules that implies ABS compliance, thus minimising bureaucracy. The combination of dedication to the respect of the ABS principles and standardized and facilitated exchanges among the group creates a sort of voluntarily "network of compliance" with ABS international rules, on which users can rely.

The Nagoya Protocol encourages Parties to develop and use voluntarily codes of conduct, guidelines and best practices in relation to ABS, and the Open-ended Ad Hoc Intergovernmental Committee (ICNP) for the Nagoya Protocol on ABS, acting as an interim governing body for the Nagoya Protocol until the first meeting of the Parties to the Protocol takes place, has been gathering and discussing recent updates of such documents. Moreover, the EU Regulation has recognized the strong efforts towards ABS compliance of the culture collections, working on the MOSAICC code of conduct even before the adoption of the Bonn Guidelines, through the creation of a register of collections established and maintained by the European Commission. Only collections that fulfill certain criteria (linked to ABS requirements) can become part of the register, and users that obtain genetic resources from a collection in the register should be considered to have exercised due diligence as regards the seeking of all information necessary from the point of view of ABS.

The $e x$ situ collections are therefore important actors in the field of ABS. Moreover, given their role in conserving biodiversity and ensuring access for scientific research purposes and their usually publicly funded origin, they provide to the society fundamental services. Their advanced raising awareness activities in the field of ABS is of paramount importance. 
II From the Right to Development to International Concern for Sustainable Use and Global Biodiversity Research

After the brief description of the main features of the international legal framework dealing with ABS, the central section of the chapter illustrates in depth the innovative hypothesis that the concept of benefit-sharing long predated the discussion on $\mathrm{ABS}$ of the $\mathrm{CBD}$, and that it is the product of the interaction between three fields of international law is here presented for the first time by the authors of this chapter, therefore the argumentations lack in references to previous literature.

\section{Rationale and Origins of the "Right to Development Motive" in the ABS Regime}

The legal framework on ABS is based on the sovereignty of states over their natural resources. The root of the principle of sovereignty over natural resources (and genetic resources, see later) is the traditional principle of international law of sovereignty and territorial jurisdiction of a state. In 1962, through its Resolution on Permanent Sovereignty over Natural Resources, the United Nations General Assembly (UNGA) recognised "the inalienable right of all States freely to dispose of their natural wealth and resources in accordance with their national interests." 28 This principle has firstly been encoded in the post-war era and it has been used as a tool by international economic law to support two main concerns of the United Nations: economic development and self-determination of colonial people. ${ }^{29}$ In the 1950 , developing countries advocated this principle to secure the benefit arising from the exploitation of natural resources and to provide newly independent states with legal tools to defend their economic sovereignty against property and contractual rights

28 Resolution 1803 (XVII) of 14 December 1962 "Permanent sovereignty over natural resources": the UNGA created in 1958 the Commission on Permanent Sovereignty over Natural Resources "to conduct a full survey of this basic constituent of the right to selfdetermination, with recommendations, where necessary, for its strengthening" and the work of the Commission resulted in the adoption of the Declaration on Permanent Sovereignty over Natural Resources in UNGA Resolution 1803. It is important to underline that Resolution 1803 of 1962 can be considered a binding Resolution, apart from the strong political force every General Assembly Resolution has, because principle 7 clarifies that the violation of the rights of peoples and nations to sovereignty over their natural wealth and resources is contrary to the spirit and principles of the Charter of the United Nations.

29 Nico J. Schrijver, "Natural Resources, Permanent Sovereignty over," Max Planck Encyclopedia of Public International Law (New York, NY: Oxford University Press, 2010). 
claimed by foreign states and companies. By 1952, the United Nations General Assembly had already underlined that the right of developing countries to determine access to their natural resources was a pre-requisite to foster their economic development "in accordance with their national interests."30

Ever since the first mention by the United Nations General Assembly, the right to use national resources has been strongly linked to the right to development. Already in 1952, Resolution 523 on "Integrated economic development and commercial agreements" underlined the root of the problem of the upcoming globalised market where the contractual power of less developed/ newly independent states in selling raw materials and resources was not proportionate to the buying states (the developed ones). The Resolution recalled that a necessary requisite for

economic development plans in under developed countries is the creation of conditions under which these countries could more readily acquire machinery, equipment and industrial raw materials for the goods and services exported by them. ${ }^{31}$

Therefore, commercial agreements should facilitate the movement of such machinery, equipment and industrial raw material for the development and improvement of standards of living in under-developed countries. Moreover such agreements "shall not contain economic or political conditions violating the sovereign rights of the under-developed countries, including their rights to determine their own plans for economic development." This first very weak safeguard of the contractual powers of the countries providing natural resources can be seen as the root of the principles of transfer of technology and mutually agreed term for the achievement of fair and equitable benefit-sharing, later codified in the Convention on Biological Diversity.

By the end of 1952, the United Nations General Assembly went back to these principles in Resolution 626 on the Right of States to exploit freely natural wealth and resources. The Resolution referred to the good faith and balance within the economic exchange of natural resources: it encouraged member States "to have due regard, consistently with their sovereignty, to the need for maintaining the flow of capital in conditions of security, mutual confidence and economic cooperation among nations." This passage is a very light obligation on states to keep a balance and avoid disproportionate flow of capital in economic

30 Resolution 523 of 12 January $195^{2}$ on Integrated economic development and commercial agreements (Preamble, first paragraph).

$31 \quad$ United Nations General Assembly Resolution 523, preamble. 
transactions with developing states, within the use and exploitation of natural resources. It can be argued that the principle of benefit-sharing echoed this UNGA call. The same Resolution also recognised the need to encourage under developed countries towards the proper use and exploitation of their natural wealth and resources, which anticipates the issue of sustainable use of resources that came to the foreground of international attention in the 1970ies. Going back to the economic exchange of natural resources another Resolution in $195^{2}$ (Resolution 523), expressly considers that "commercial agreements shall not contain economic or political conditions violating the sovereign rights of the under-developed countries, including the right to determine their own plans for economic development." ${ }^{2}$ Another step forward was taken ten years later, with Resolution 1803 of 1962, which underlines that "economic and financial agreements between the developed and the developing countries must be based on the principles of equality and of the right of peoples and nations to self-determination."33 International soft law is here interfering with national commercial practices in favour again of an economic balance in the exchange of natural resources. Resolution 1803 of 1962 goes even further by stating that in case where authorization for activities of exploration, development and disposition of national natural resources is granted by a state to a foreigner, the profits arising from such activity "must be shared in the portions freely agreed upon, in each case, between investors and the recipient state." It also added that "due care being taken to ensure that there is no impairment, for any reason, of that State's sovereignty over its natural wealth and resources." This text is the origin of the modern principles of prior informed consent and benefit-sharing upon mutually agreed terms.

Another highly relevant factor is the fact that Resolution 1803 focused also on people and not only on the State. It specified that

the right of peoples and nations to permanent sovereignty over their natural wealth and resources must be exercised in the interest of theirnational development and of the well-being of the people of the State concerned.

This principle, even if not yet related to the awareness of the key role of indigenous and local communities in the conservation and sustainable use of biological diversity, laid the ground for the later work for the social movements in

\footnotetext{
32 Resolution 523 of 12 January $195^{2}$ on Integrated economic development and commercial agreements paragraph. 1 (b).

33 United Nations General Assembly Resolution 1803 (XVII) on Permanent sovereignty over natural resources, Preamble.
} 
defence of the specific rights of these communities in the context of the access and benefit-sharing regime.

In 1974, during the Sixth Special Session of the General Assembly exclusively devoted to the problems of raw materials and development, the UNGA adopted Resolution 3201 entitled Declaration on the Establishment of the New International Economic Order (NIEO Declaration), submitted by the Group of 77 made up of nearly all developing countries. The NIEO Declaration proclaimed "full permanent sovereignty of every State over its natural resources and all economic activities,"34 including the right to nationalise resources or to transfer their ownership to nationals. The NIEO Declaration thus reinforced principle 10 of the Stockholm Declaration ${ }^{35}$ (see Section II.2) by calling for a just and equitable relationship between the prices of raw materials, primary commodities, manufactured and semi-manufactured goods exported by developing countries and those imported by them. From that point onwards, the motive of the right to development easily lead international law-making and the reaffirmation of the claims of sovereignty over natural resources in the Convention on Biological Diversity.

From 1970ies onwards, the growing discussions on the looming global environmental crisis reinvigorated the right to development claim and the related sovereignty rights, as developing countries saw "the possibility of linkage between environmental concerns and reform of the international economic order."36 The 1971 Founex Report on Development and Environment ${ }^{37}$ was the first authoritative study placing the environment-development nexus on the international agenda. As a consequence, Principle 11 of the Stockholm Declaration already called for "environmental policies of all States [to] enhance and not adversely affect the present of future development potential of developing countries"; 38 and "resources should be made available to preserve and improve the environment" ${ }^{\prime 39}$ with a special attention to developing countries and the costs they have to face to incorporate environmental concerns in their development plans.

\footnotetext{
$34 \quad$ NIEO Declaration Paragraph 4 (e).

35 Declaration of the United Nations Conference on the Human Environment, U.N. Doc. A/Conf.48/14/Rev. 1 (1973); 11 ILM 1416 (1972).

36 Marc Williams, "Re-Articulating the Third World Coalition: The Role of the Environmental Agenda," Third World Quarterly 14 (1993): 15.

37 Founex Report on Development and Environment: a Report Submitted by a Panel of Experts Convened by the Secretary General of the United Nations Conference on the Human Environment, June 4-12, 1971, in 586 International Conciliation 7 (1972).

38 Stockholm Declaration Principle 11.

39 Stockholm Declaration Principle 12.
} 
In the years following the Stockholm Conference, the call for the right to development further echoed in the global governance arena. The 1974 UNEP/ UNCTAD Cocoyoc Conference, for instance, is a watershed moment for modern environmentalism ${ }^{40}$ and paved the way for contemporary ABS principles. The Conference' Declaration explicitly supported "the setting up of strong international regimes for the exploitation of common property resources" and the idea of using the international commons "for the benefit of the poorest strata of the poor countries." 41

Finally, the strengthening of sovereign rights over genetic resources and traditional knowledge should also be understood as a reaction to expanding enclosure of biological material through intellectual property rights. More particularly, the start of GATT's Uruguay Round in 1986 and the discussions on the Trade Related Aspects of Intellectual Property Rights (TRIPS), triggered by a booming biotechnology industry, expanded the use of patents to biotechnology. In this context, developing countries "abandoned the common heritage strategy and successfully demanded reconfirmation of national sovereign rights over genetic resources." ${ }^{42}$ Paradoxically, the call for increased sovereign control over genetic resources was used by developed countries to justify the expansion of intellectual property rights over these resources. In order to reap the benefits from this increased sovereignty, profits had to be generated, which required the establishment of a market and a mechanism for intellectual property protection, so the argument went. ${ }^{43}$ The idea of genetic resources and traditional knowledge as a new source of economic prosperity thus appealed to developed and developing countries alike. This is why, in addition to increased sovereignty, the Convention on Biological Diversity also recognizes the need for intellectual property rights.

The right to development, triggered by the unequal international political and economic order of the 2oth century, thus can be said to have laid the

40 The Cocoyoc Declaration inter alia coined the term "eco-development," i.e. "ecologically sound socioeconomic development," which paved the way for the concept of sustainable development.

Cocoyoc Delcration, adopted by the participants in the UNEP/UNCTAD symposium on "Patterns of Resource Use, Environment and Development Strategies," Cocoyoc, Mexico, 8-12 October, 1974.

Kristin Rosendal, "The Convention on Biological Diversity: Tensions with the WTO TRIPS Agreement over Access to Genetic Resources and the Sharing of Benefits," in Institutional Interaction in Global Environmental Governance: Synergy and Conflict among International and EU Policies, eds. Oberthür and Gehring (Cambridge: MIT Press, 2006): 86.

Kal Raustiala and David G. Victor, "The Regime Complex for Plant Genetic Resources," International Organization 58 (2004): 277-309; Hufty, "La gouvernance internationale de la biodiversité." 
groundwork of the claim for "fair and equitable sharing of benefits," the third objective of the CBD. In this regard, the strong claim for sovereignty was seen by developing countries as the only tool to exercise legal protection and acquire benefit-sharing, while developed countries relied on intellectual property rights to get benefits and to get back some of their investments in research. Benefit-sharing then emerged to counterbalance the strong IPRs assets built up by developed countries, and as compensation for the keepers of traditional knowledge.

\section{Rationale and Origins of the "Sustainable Use Motive" in the ABS Regime}

International standards and objectives for the prevention or mitigation of environmental harm have been established from the 1940's onwards. ${ }^{44}$ The regulation of biological diversity first grew into a global priority with the international environmental negotiations back in the 1970 's, ${ }^{45}$ supported both by conservationist pleas and requests for financial compensations deriving from the use of genetic resources.

Before the initiation of global environmental governance in the 1970's, the international regulation of genetic resources had long remained an untamed and singular creature. Indeed, most of the environmental regulations had formerly been concerned with "truly" global resources, such as air for example, where "joint international strategies for their use, conservation and development have to be agreed." ${ }^{\prime 6}$ As such and in their material form, biological resources are linked to land and thus domestic in nature, as public or private tangible goods, subject to the property regime set out in national laws. However, the information found within these resources' genotypes possess global public goods qualities. ${ }^{47}$ Genetic resources thus do not conform to the traditional

44 International environmental agreements include purpose-specific conventions such as the 1946 International Convention for the Regulation of Whaling (ICRW); regional agreements such as the 1976 Barcelona Convention for Protection against Pollution in the Mediterranean Sea; and also cross-cutting agreements such as the 1973 CITES Convention on International Trade in Endangered Species of Wild Fauna and Flora.

45 See Philippe Sands, Principles of International Environmental Law (second edition) (Cambridge University Press, 2003): 25-69.

46 As for instance the regulation of the ozone layer and its 1985 Vienna Convention and 1987 Montreal Protocol on Substances that Deplete the Ozone Layer; Timothy Swanson, "Why Is There a Biodiversity Convention? The International Interest in Centralized Development Planning," International Affairs 75 (1997): 307-308.

47 Joseph Straus, "The Rio Biodiversity Convention and Intellectual Property," International Review of Industrial Property and Copyright Law 24 (1993): 602-603. 
definition of global resources in international environmental law making. It is important to note that in the first international environmental instruments, natural resources were only considered as tangible goods, raw materials. Therefore, the aspect that was the target of regulation was the quantitative transaction for the economic exploitation of the resources, as knowledge on genetic resources was scarce in the 1950 os and 1960 . ${ }^{48}$

Biodiversity depletion concerns were however gradually recognised on account of a "confluence of international dialogues that have existed for several decades," including but not limited to debates focusing on protected areas, the sustainable use of natural resources or environmental funding, and the international environmental law concerned with biological resources was developed as a "snapshot of environmental conservation movements." ${ }^{49}$ Its more progressive pleas also include the desire to overcome the existing patchwork of regulation covering selected species or areas, mainly through an ecosystems approach, ${ }^{50}$ but also to address the issue of informational goods that are part of such ecosystems.

With the 1972 Stockholm Declaration of the United Nations Conference on the Human Environment, the duty that accompanied sovereign rights over resources shifted from a right to use resources to a "responsibility to protect and improve the environment for present and future generations." ${ }^{51}$ Although states have permanent sovereignty over their natural resources and the right to determine their own environmental policies, they are not free to disregard protection of the environment of common spaces or of other states. Nevertheless, developmental needs remain an obstacle to stronger environmental regulation for developing and developed economies alike. ${ }^{52}$ The Declaration specified

48 The 1949 United Nations Scientific Conference on the Conservation and Utilisation of Resources, made up of technical experts, focused on specific groups of natural resources such as land, water, forests, fuels, minerals, and wild life, included a session on land natural resources, which also included chemurgy, food yeasts, and microorganisms. The conference concentrated on shortage of resources due to increase of population and demand, rather than the importance of the still unknown research information contained within microorganisms. No or little consideration was given to resources as objects of research, neither to what was then identified as the information contained in genetic material.

49 Timothy Swanson, "Why Is There a Biodiversity Convention? The International Interest in Centralized Development Planning," International Affairs 75 (1): 307-331.

50 International Law of relevance to Plant Genetic Resources: a practical review for scientists and other professionals working with PGR. (2004).

$5^{1} \quad$ Stockholm Declaration Principle 1.

52 Patricia Birnie and Alan Boyle, International Law and the Environment (Oxford University Press, 2001). 
that "environmental policies of all States should enhance and not adversely affect the present or future development potential of developing countries"; 53 and "resources should be made available to preserve and improve the environment" 54 with a special attention to developing countries and the costs they have to face to incorporate environmental concerns in their development plans. Therefore the Stockholm Declaration called for the mobilisation of monetary resources as an incentive for developing countries to adopt environmental legislations. The origin of benefit-sharing lays in this exchange of monetary resources as an incentive for under developed countries. Amongst other endeavours having followed the Stockholm Declaration, a soft-law instrument acknowledging mankind's responsibility for all species inhabiting the Earth had seen the light of day through United Nations General Assembly Resolution 37/7 in 1982, commonly referred to as the "World Charter for Nature." The Charter asserted that "the degradation of natural systems owing to excessive consumption and misuse of natural resources [...], leads to the breakdown of the economic, social and political framework of civilization."

Owing to these steps, the official advent of biodiversity came about during the process leading to the 1992 United Nations Conference on Environment and Development, ${ }^{55}$ otherwise known as the "Earth Summit" and the adoption of the Convention on Biological Diversity. ${ }^{56}$ The Convention on Biological Diversity is the product of the philosophy of sustainable development, where the goal of environmental protection needs to be balanced with the need and right to development.

Despite the preservation objective, the CBD also embodies a shift towards a utilitarian economic exploitation of the resources, albeit in a sustainable way. The growing attention to environmental protection does not only derive from sudden awareness of the intrinsic value of natural wealth and/or from a better understanding of the functioning of ecosystems. Indeed, as early as the energy crises of the 1970ies, developing countries increasingly saw their natural resources as an important strategic and economic bargaining chip. This led to

\footnotetext{
53 Stockholm Declaration Principle 11.

54 Stockholm Declaration Principle 12.

55 The first stages of the adoption of the CBD can be traced back to a 1981 Resolution adopted by the World Conservation Union's General Assembly, requesting further analysis on a potential international agreement on the conservation, accessibility and use of biological resources; see Regine Andersen, Governing Agrobiodiversity. Plant Genetics and Developing Countries (Ashgate, 2008): pp. 117-119, citing C. De Klemm, "Conservation of species: The need for a new approach," Environmental Policy and Law 9 (1982): 118-128.

$5^{6}$ Opened for signature on 5 th June 1992, the CBD entered into force on 29th December 1993.
} 
a growing understanding on the fact that the availability of genetic diversity and traditional knowledge as a raw material for the biotechnology industry can only be guaranteed through the protection of a strong variety of in situ ecosystems (including humans), which is to be found in developing countries. ${ }^{57}$ Unlike in the 6os and 7os, developed countries started questioning the effectiveness of so-called "fortress conservation," through which large areas of "virgin" nature where freed from human interaction, and increasingly promote in situ conservation and the concept of "sustainable use" of biodiversity. ${ }^{58}$ As underlined in Section I.1 as an effect of negotiation bargain between developing countries and developed ones, the second and third objectives of the Convention thus became the "sustainable use of its components and the fair and equitable sharing of the benefits arising out of the utilisation of genetic resources." 59

The exchange of monetary resources as an incentive for the conservation of biological diversity in developing countries was further institutionalized in the CBD. Article 3 of the CBD reaffirms "the sovereign right (of States) to exploit their own resources pursuant their own environmental policies": this indicates a balance between national environmental policies and, again, the right of States to their economic development. ${ }^{60}$ The only limit put to such prerogative seems to be the responsibility to ensure that activities within their jurisdiction or control do not cause damage to the environment of other States or of areas beyond the limits of national jurisdiction. ${ }^{61}$ This focus on development echoed the approach of Rio Declaration on Environment and Development that had shifted from an environmental to a development one. The Rio Declaration in fact makes no reference to the conservation of flora, fauna, habitats and ecosystems. ${ }^{62}$ However, the CBD focuses on in situ conservation and the protection of ecosystems, natural habitats (Article 8.d), re-appropriating the conservation angle of the Stockholm Declaration.

The focus on utilisation and exploitation goes along with a broader change in global environmental governance, which is the confluence of the neo-liberal economic order of the 8os and gos and environmental protection (termed

\footnotetext{
57 Lipietz, "Enclosing the Global Commons."

58 Marian A.L. Miller, The Third World in Global Environmental Politics (London: Lynne Rienner, 1995).

59 CBD Article 1, emphasis added.

6o CBD Article 3, emphasis added.

$61 \quad$ Ibid.

$62 \quad$ Schrijver, "Natural Resources."
} 
"liberal environmentalism"). ${ }^{63}$ With the Brundtland report, ${ }^{64}$ more economic growth (mainly through liberalized market-mechanisms for environmental management) was pictured as the solution for the protection of the environment. This was partially made possible through the extended sovereignty over natural resources and the developing countries' call for a compromise between development and environmental protection. In the ABS context, the sustainable use approach thus can be seen as a compromise position between developed countries (who need genetic resources for biotechnology), developing countries (who expect financial returns in exchange with granted access to their genetic resources) and global environmental groups ("newly enchanted by market mechanisms"). ${ }^{65}$

The liberal environmentalism approach of the CBD is further exemplified by the fact that the CBD originally did not contain language on the obligation to devote the benefits to conservation of biological diversity. The underlying view was that biological diversity served the purpose of utilization, which on its turn generated benefits and allowed for development in developing countries. In line with the right to self-determination and to development, provider countries could decide to use the monetary benefits acquired through a benefit-sharing arrangement as they saw fit. However, this was partially redressed in the 2002 Bonn Guidelines, ${ }^{66}$ which recommended redirecting benefits towards measures for the conservation of biological diversity and the sustainable use of its components. The Nagoya Protocol further strengthened this encouragement. ${ }^{67}$

\section{Rationale and Origins of the "Scientific Research Motive" in the Global ABS Regime}

The research community is arguably the stakeholder group most affected by access and benefit-sharing under the CBD and the Nagoya Protocol: access to genetic resources in almost all cases is undertaken with no commercial intent at the time of access. ${ }^{68}$ It has been demonstrated that at the time when the

63 Steven Bernstein, "Liberal Environmentalism and Global Environmental Governance," Global Environmental Politics 2 (2002): 1-16.

64 Brundtland G.H. and World Commission on Environment and Development, Our common future: report of the World Commission on Environment and Development (Oxford University, 1987).

65 Raustiala and Victor, “The Regime Complex for Plant Genetic Resources."

66 CBD, Bonn Guidelines on Access to Genetic Resources and Fair and Equitable Sharing of the Benefits Arising out of their Utilization, 2002.

$67 \quad$ Nagoya Protocol Article 9.

68 Matthias Buck and Claire Hamilton, "The Nagoya Protocol on Access to Genetic Resources and the Fair and Equitable Sharing of Benefits Arising from their Utilisation to the 
entry into force of the CBD was approaching (end of 1993), the amount of exchange of plant genetic resources in food and agriculture for public research purposes, within the Consultative Group on International Agricultural Research, dropped considerably as a result of the re-affirmation of national sovereignty over genetic resources under the CBD, in conjunction with the fear of legal uncertainty over intellectual property right. ${ }^{69}$

The importance of international cooperation for biodiversity research has been recognized early on in the broader context of the debates in international environmental soft law. The Stockholm Declaration underlines that the "free flow of up-to-date scientific information and transfer of experience must be supported and assisted, to facilitate the solution of environmental problems; environmental technologies should be made available to developing countries." ${ }^{70}$ This requirement has been reiterated by the Rio Declaration on Environment and Development that goes further in calling for states to "cooperate to strengthen endogenous capacity-building for sustainable development by improving scientific understanding through exchanges of scientific and technological knowledge, and by enhancing the development, adaptation, diffusion and transfer of technologies, including new and innovative technologies."71 In 1992 the Rio Declaration is putting forward the innovative idea that cooperation is aimed at strengthen endogenous capabilities rather than focusing only on the transfer of technologies, which is more passive and less effective in the view of developing countries.

The need for international scientific cooperation has been inspiring also the international law making of some international binding treaties: the United Nations Convention on the Law of the Sea, ${ }^{72}$ the Antarctic Treaty ${ }^{73}$ and the FAO's International Treaty on Plant Genetic Resources for Food and Agriculture contain important obligations to this regards.

The whole Antarctic Treaty System (ATS), ${ }^{74}$ whose origin dated in 1959 when the Antarctic Treaty was signed, is focused on scientific research and the

Convention on Biological Diversity," Review of European Community \& International Environmental Law 20 (2011): 59 .

69 Michael Halewood, "Governing the management and use of pooled microbial genetic resources: Lessons from the global crop commons," International Journal of the Commons $4(2010): 403$.

70 Stockholm Declaration Principle 20.

$71 \quad$ Rio Declaration Principle 9.

72 United Nations Convention on the Law of the Sea, 1982, 21 ILM (1982), 1261.

731959 Antarctic Treaty, 19 ILM 860 (1980).

74 The Antarctic Treaty System is the whole complex of arrangements made for the purpose of regulating relations among states in the Antarctic. At its heart is the Antarctic Treaty 
promotion of international scientific cooperation. The main objectives of the Antarctic Treaty are to demilitarize Antarctica and to ensure that it is used for peaceful purposes only; to promote international scientific cooperation and to set aside disputes over territorial sovereignty. ${ }^{75}$ Contracting Parties are obliged to exchange scientific information, personnel and results "to the greatest extent feasible and practicable." 76

The 1982 United Convention on the Law of the Sea (UNCLOS) does not mention genetic resources for historical reasons, but prescribes important rules for the organization of marine scientific research (MSR), which can be considered to apply to genetic resources. The UNCLOS requires States and international organization (indeed stressing the aspect of international cooperation) to promote and facilitate the development and conduct of marine scientific research. ${ }^{77}$ MSR, notwithstanding in which maritime area it is conducted, must have peaceful purpose, respect the whole system of the law of sea (protection of the marine environment included) and cannot be the legal basis for claim of appropriation of marine environment and resources. ${ }^{78}$ International cooperation in MSR is to be promoted and to this end states and international organizations are required to make available information on proposed major programmes, their objectives and the knowledge resulting from MSR. ${ }^{79}$ These obligations to share knowledge produced through marine scientific research constitute non-monetary benefit-sharing obligations of the UNCLOS ${ }^{80}$ that are applicable both in areas within national jurisdiction and in areas beyond national jurisdiction. Moreover States "shall actively promote the flow of scientific

itself. The Treaty is augmented by Recommendations adopted at Consultative Meetings, by the Protocol on Environmental Protection to the Antarctic Treaty (Madrid, 1991), and by two separate conventions dealing with the Conservation of Antarctic Seals (London 1972), and the Conservation of Antarctic Marine Living Resources (Canberra 1980).

75 Antarctic Treaty Article I-IV.

76 Antarctic Treaty Article III.

77 UNCLOS Article 241.

78 UNCLOS Article 240-241.

79 UNCLOS Article 244.1.

80 Greiber Thomas, "Common Pools for Marine Genetic Resources," in Common Pools of Genetic Resources. Equity and Innovation in International Biodiversity Law, eds. Kamau and Winter (Earthscan, 2013), 407. Broggiato Arianna, et al., "Fair and equitable sharing of benefits from the utilization of marine genetic resources in areas beyond national jurisdiction: Bridging the gaps between science and policy," 49 Marine Policy (2014), 176. IUCN Information Papers for the Intersessional Workshop on Marine Genetic Resources 2-3 May 2013, available at http://www.un.org/depts/los/biodiversityworkinggroup/documents/ IUCN\%2oInformation\%2oPapers\%2ofor\%2oBBNJ\%2oIntersessional\%2oWorkshop\%20 on\%2oMGR.pdf. 
data and information and the transfer of knowledge resulting from marine scientific research, especially to developing States, as well as the strengthening of the autonomous marine scientific capabilities of developing States." ${ }^{81}$ This focus on the development of own scientific capabilities of developing countries was innovative at that time. It survived and inspired the 1992 Rio Declaration (as seen above) but it was lost in favor of the more passive technology transfer obligation emerged in the negotiation of the CBD, that same year (see below).

The 1984 International Undertaking on Plant Genetic Resources, as well as the ITPGRFA, adopted a research oriented approach: access to resources is to be facilitated for research purposes, plant breeding and conservation. ${ }^{82}$ The International Undertaking is about collaboration on research and interdependency rather than direct commercial use. The ITPGRFA is also a research oriented treaty rather than an environmental one. It stresses the importance of international cooperation and transfer of technologies.

However, with the above-mentioned exceptions (the United Nations Convention on the Law of the Sea, the Antarctic Treaty and the FAO's International Treaty on Plant Genetic Resources for Food and Agriculture), the international legal framework has been limited to the "commercial" end of the research chain and focused mainly on the issues surrounding technology transfer and intellectual property rights. As a result, outside the specific areas of application of these international agreements, there is not clear legal framework under public international law establishing the rights and duties of global research collaborations with basic knowledge assets for scientific research, in spite of evidence of increasing restrictions on access to basic research assets in areas such as scientific publishing; ${ }^{83}$ access to research samples ${ }^{84}$ and access to databases. ${ }^{85}$

As illustrated in Section I.1 the CBD requires the states to "promote and encourage research which contributes to the conservation and sustainable use of biological diversity." However, within the implementation of the CBD, growing protectionism by developing countries and issues related to intellectual

$81 \quad$ UNCLOS Article 244.2.

82 International Undertaking Article 5; International Treaty on Plant Genetic Resources Article 12.3.

83 "Open sesame - When research is funded by the taxpayer or by charities, the results should be available to all without charge," The Economist (14 April 2012).

84 Sikina Jinnah and Stephan Jungcurt, "Could Access Requirements Stifle Your Research?" Science 323 (2009): 464-465.

85 Jerome Reichman and Ruth L. Okediji, Empowering Digitally Integrated Scientific Research: The Pivotal Role of Copyright Law's Limitations and Exceptions, 2009. 
property rights in developed countries impacted the world of scientific research and its access to resources for research purposes. At the same time many parties were concerned that special treatment for research could create loopholes in the system of ABS compliance to the detriment of countries providing genetic resources. ${ }^{86}$ Due to these emerging constraints the scientific community pushed for a facilitated access for research purposes within the negotiation of the Nagoya Protocol, but the colliding interests at stake generated a compromising article far from been clear.

The rationale of Article 8a of the Nagoya Protocol is to create legislative conditions to promote and encourage research which contributes to conservation and sustainable use of biological diversity i.e., to the first and second objective of the CBD. To this end, Article 8a of the Nagoya Protocol singles out the adoption of simplified measures to access genetic resources for noncommercial purposes as a tool to promote and encourage this research. Other tools are possible as well, but legislation in provider countries, if adopted, "shall" provide for simplified measures to access genetic resources for noncommercial research that contribute to conservation and sustainable use of biological diversity. Moreover, when such simplified procedure is adopted in drafting national ABS legislation, it needs to take into account and define the issue of "change of intent." Nevertheless, some crucial concepts in this provision still need to be clarified through practice or further legislative development: ${ }^{87}$ where does the limit between commercial and non-commercial research lay? How to demonstrate that research is aimed at the conservation and sustainable development of biodiversity? And how to identify a change of intent?

The main contribution, in this context, of the Nagoya Protocol's provision on simplified procedure to access materials for non-commercial purposes is that it offers new opportunities by explicitly including provisions that address

86 Buck and Hamilton, "The Nagoya Protocol on Access to Genetic Resources and the Fair and Equitable Sharing of Benefits Arising from their Utilisation to the Convention on Biological Diversity," 59; Evanson C. Kamau, Bevis Fedder and Gerd Winter, “The Nagoya Protocol on Access to Genetic Resources and Benefit Sharing: What is New and what are the Implications for Provider and User Countries and the Scientific Community?" Law, Environment and Development Journal 6 (2010): 256.

$87 \quad$ The precise manner in which these provisions of the Nagoya Protocol will have an impact on global research collaborations with basic knowledge assets for scientific research is still a question of intense debate: Tom Dedeurwaerdere et al., "Governing Global Scientific Research Commons under the Nagoya Protocol," in The Nagoya Protocol in Perspective: Implications for International Law and Implementation Challenges, eds. Elisa Morgera, Matthias Buck and Elsa Tsioumani (Leiden/Boston: Brill/Martinus Nijhoff, 2012). 
the global organization of scientific collaboration at the non-commercial stages of the research cycle. ${ }^{88}$

The EU ABS Regulation recalls the Nagoya Protocol's obligation to promote and encourage research related to biological diversity, in particular research with non-commercial intent. It will be interesting to see what innovative solutions are proposed by the different national legislations implementing the Nagoya Protocol and the EU ABS Regulation.

\section{Overview of the Book}

The law-making on genetic resources culminated with the adoption of the Nagoya Protocol to the Convention on Biological Diversity. In order to evaluate if the Protocol offers an adequate balance between the three motives that characterized the law making on genetic resources - the right to development of the developing countries, the global environmental concerns and the need of the research community to have smooth and rapid access to biological materials - it is necessary to gather the most up to date knowledge on the ongoing implementation efforts of the Nagoya Protocol in Europe. The aim of this book is to comparatively analyse the heterogeneous legal and institutional state of the art of access and benefit-sharing instruments in Europe, and to identify cross-cutting issues for the forthcoming implementation of the Nagoya Protocol in the EU, within the framework of the EU Regulation on Access and Benefit-sharing.

The focus of this book is a comparative analysis of the heterogeneous legal and institutional state of the art of access and benefit-sharing instruments in Europe, in light of the forthcoming implementation of the Nagoya Protocol within the EU.

Through its recently adopted EU Regulation on Access and Benefit-sharing, ${ }^{89}$ aiming at implementing the Nagoya Protocol in the European Union, the European Commission establishes an EU-harmonised approach on ABS, creating

88 Jerome H. Reichman, Tom Dedeurwaerdere and Paul Uhlir, Global Intellectual Property Strategies for the Microbial Research Commons (Cambridge: Cambridge University Press, forthcoming).

89 Regulation (EU) No 511/2014 of the European Parliament and of the Council of 16 April 2014 on compliance measures for users from the Nagoya Protocol on Access to Genetic Resources and the Fair and Equitable Sharing of Benefits Arising from their Utilization in the Union. Official Journal of the European Union L 150/59, 20.05.2014. 
a level playing field for European users. According to the Regulation, this harmonized approach only entails minimum features which are to be complemented with existing ABS systems and best practices left to the choice of users of genetic resources. However, current instruments strongly differ in terms of depth, scope and effectiveness as well as across different types of users. Furthermore, it is likely that the utilization of genetic material is already (directly or indirectly) regulated by private and public law provisions-if not by specific ABS laws-which will be impacted by a harmonization at EU level. This is further complexified by the plurality of political structures and the division of competences within member states, as well as by the different utilization profiles of member states (user, provider or both).

The implementation of the EU Regulation on ABS is offering a unique opportunity for the reassessment of the national legislative framework in European and non-EU countries, and this collective volume aims to shed light on this heterogeneity from an academic perspective.

The first part of the book, "Access and Benefit-sharing Regimes in Europe," provides detailed case-studies of ABS frameworks in selected European countries (including non-EU countries, like Norway and Turkey). Drafted by national ABS experts, these country case-studies were conducted on the basis of the following common research questions:

(1) Legal status of genetic resources and traditional knowledge: Under currently applicable law, what is the legal status of genetic resources and associated traditional knowledge in your country?

(2) Access to domestic genetic resources and traditional knowledge: Is access to genetic resources and associated traditional knowledge regulated in your country? How?

(3) Benefit-sharing mechanisms: Which benefit-sharing obligations can be found in currently applicable law in your country?

(4) Compliance mechanisms: Can PIC and MAT currently be controlled/ enforced in your country on the basis of specific legislation and/or general private international law principles?

(5) Distribution of competences: How are ABS-related competences politically and administratively distributed in your country?

These chapters shows that the economic, historical and social developments of each country, together with its geographical and environmental conditions, have deeply influenced the choices these countries have been making and are making in balancing the conservation of biodiversity, their efforts to acquire a better economic development and the support they are willing to give to 
research in the field of biodiversity and to its necessity to have a smooth and easy access to natural resources.

The second part of the book, "Implementing the Nagoya Protocol in the European Union," explores several cross-cutting issues related to the implementation of the Nagoya Protocol in the EU.

Chapter 11 by Philippe Karpe, Alexis Tiouka, Ivan Boev, Armelle Guignier and Florencine Edouard underlines the importance of protecting traditional knowledge of the Amerindians of French Guyana and the possibility to implement this protection through the use of indigenous customary law and their existing autonomy. It however stresses the limitation of this protection. The contribution looks into the opportunity given by the implementation of the EU Regulation on compliance measures for users from the Nagoya Protocol to improve effective protection of traditional knowledge.

Chapter 12 by María Julia Oliva introduces the development of private standards, as particular kinds of best practice or voluntary norms, and their benefits towards compliance with ABS requirements. These requirements are developed through multi-stakeholder consultation. In meeting the challenge of monitoring and evaluating utilization of genetic resources for compliance with ABS requirements, private standards bring to bear relevant traceability systems, reporting requirements and independent audits. They are likely to be helpful in implementing the due diligence principle of the EU ABS Regulation.

Chapter 13 by Christine Godt argues that the EU approach camouflages a simplistic understanding of how the uses of genetic resources are regulated in detail. The approach ignores the administrative set-up of various pre-existing procedures, which fine-tune in many ways, the quality control of research and production. It willfully downplays the difficulties of information flow, and gives broad leeway to circumvention. Thus, it shows that the EU ABS Regulation focusing on user measures is not ambitious enough to complement existing and future provider measures.

Chapter 14 by Lorenzo Maggioni, Isabel López Noriega, Isabel Lapeña, Vojtech Holubec and Johannes Engels presents and analyses current and potential difficulties for collecting plant germplasm in situ in Europe. These difficulties are the result of the combination of international rules on access and benefit-sharing with pre-existing national laws and administrative procedures that both add complexity and influence the way international conventions are implemented. This contribution offers some ideas about how the objective of providing facilitated access to plant genetic resources, which is embraced by the CBD, the Treaty and the Nagoya Protocol, can be effectively achieved in European countries. 
The conclusion to the book by Brendan Coolsaet articulates a comparative analysis of the ABS regimes in Europe, based on the country case-studies, and outlines a comprehensive evaluation of the challenges related to the implementation of the Nagoya Protocol in the EU, taking into account the provisions of the EU Regulation on ABS and the input provided by the chapters of the second part of this book. ${ }^{90}$

9o See contribution by Coolsaet to this volume (Conclusion). 